\title{
Safety and Efficacy of Treatment of Pediatric Cholesteryl Ester Storage Disease with Lovastatin
}

\author{
CHARLES J. GLUECK, PHILIP LICHTENSTEIN, TRENT TRACY, AND JAMES SPEIRS
}

Jewish Hospital Cholesterol Center, Cincinnati, Ohio 45229

\begin{abstract}
The aim of this study was to prospectively assess the safety and efficacy of lovastatin in the treatment of cholesteryl ester storage disease in siblings who were ages 11.6 and $5 \mathrm{y}$ at the beginning of treatment. Mean total and LDL cholesterol in the male proband, 7.40 and 5.68 $\mathrm{mmol} / \mathrm{L}$, respectively, on diet alone, fell $30 \%$ to $5.2(p \leq$ $0.001)$ and $31 \%$ to $3.9 \mathrm{mmol} / \mathrm{L}(p \leq 0.001)$ on lovastatin $40 \mathrm{mg} / \mathrm{d}$ over $3.3 \mathrm{y}$, with simultaneous resolution of hepatosplenomegaly. In his sister, on lovastatin $20 \mathrm{mg} / \mathrm{d}$ for 1.5 $y$, total and LDL cholesterol fell, but not significantly; her hepatosplenomegaly was also reduced on treatment. Lovastatin was well tolerated without overt side effects or complications and without adverse changes in liver function tests or creatine phosphokinase. Normal and expected accretion of height and weight occurred during the treatment period for both children. Lovastatin appears to be a safe and effective treatment for pediatric cholesteryl ester storage disease. (Pediatr Res 32: 559-565, 1992)
\end{abstract}

Abbreviations

CESD, cholesteryl ester storage disease LDLC, low density lipoprotein cholesterol HDLC, high density lipoprotein cholesterol CPK, creatine phosphokinase GGT, $\gamma$-glutamyl transferase SGPT, serum glutamate pyruvate transaminase

CESD is a rare, recessively inherited disorder characterized by very low or unmeasurable levels of the hepatic lysosomal enzyme cholesteryl ester hydrolase (1-14). Patients with CESD usually have hepatosplenomegaly because of hepatic lysosomal sequestration of cholesteryl ester and commonly have high plasma cholesterol, LDLC, and triglycerides and very low levels of HDLC. High LDLC and low HDLC in CESD patients puts them at markedly increased risk for premature coronary artery disease. Moreover, ongoing storage of cholesteryl esters in the hepatic lysosomes, augmented by hyperlipidemia, leads to progressive hepatosplenomegaly. Consequent complications may include hepatic fibrosis, cirrhosis, and liver failure, with associated portal hypertension, varices, and hypersplenism.

Until the recent availability of lovastatin (1, 10, 11), CESD could not be satisfactorily treated because diet and other lipid lowering drugs were not effective. In 1987, successful therapy of CESD with the newly available hydroxymethylglutaryl-CoA reductase inhibitor, lovastatin, was reported by Ginsberg et al. (1).

Received April 21, 1992; accepted June 29, 1992.

Correspondence and reprint requests: C. J. Glueck, M.D., Cholesterol Center, Jewish Hospital, 3200 Burnet Ave, Cincinnati, OH 45229.

Supported by the Lipoprotein Research Fund, Jewish Hospital of Cincinnati.
In a 9-y-old girl with CESD who had severe hypercholesterolemia, hypertriglyceridemia, and very low HDLC, lovastatin (40 $\mathrm{mg} / \mathrm{d}$ ) reduced total cholesterol from 7.89 to $4.81 \mathrm{mmol} / \mathrm{L}$, reduced LDLC from 6.05 to $3.31 \mathrm{mmol} / \mathrm{L}$, and increased HDLC from 0.72 to $0.98 \mathrm{mmol} / \mathrm{L}$ over an 8 -mo period of therapy (1). On lovastatin, she had normal increases in height and weight and no evidence of any adverse effects of treatment. The sizes of her liver and spleen were stable during the treatment period, as assessed by liver and spleen scans. Histologic examination of a repeat liver biopsy after treatment indicated no significant change in the degree of cholesteryl ester accumulation (1). Ginsberg et al. (1) reported that the absolute delivery of cholesteryl ester to hepatic lysosomes was reduced by lovastatin therapy. In addition, total apo B flux and cholesterol flux were diminished (1). Plasma VLDL and LDLC levels were thought to be reduced by upregulation of the hepatic LDL receptor by lovastatin, by diminished cholesterol synthesis, and by reduced rates of apo B production in both VLDL and LDL (1). Additional short-term studies of the effective $(10,11)$ and safe $(10-12)$ treatment of CESD in children with lovastatin have recently been published.

The aim of the current study was to prospectively assess the safety and efficacy of treatment of CESD (1-14) with lovastatin for 3.3 and $1.5 \mathrm{y}$, respectively, in a brother and sister with CESD ages 10.5 and $2 \mathrm{y}$ at the beginning of follow-up.

\section{MATERIALS AND METHODS}

Patients. The proband, a 7-y-old Caucasian male, was identified when, after the resolution of an acute-onset viral-type syndrome (characterized by diffuse lymphadenopathy, cold agglutinin-positive hemolytic anemia, and protracted fever), marked hepatosplenomegaly (liver span $14 \mathrm{~cm}$, spleen down $5 \mathrm{~cm}$ ) persisted. His younger sister, born $1 \frac{1 / 2}{2}$ y later, was followed prospectively from birth and developed hepatomegaly at age 6 mo. Percutaneous liver biopsies, performed at the Children's Hospital Medical Center in Cincinnati when the proband was $71 / 2$ y old and his sister was $1 \frac{1}{2}$ y old, revealed characteristic features of $\operatorname{CESD}(2,5-8)$ with massive accumulation of cholesteryl esters in lysosomes along with hepatic fibrosis (indicating early cirrhosis).

Lipid and lipoprotein determinations. Serial determinations of lipids and lipoprotein cholesterols in plasma after a 12-h fast were carried out by enzymatic methods (15-18) in our Lipid Research Clinic standardized laboratory (19).

Study protocol. In both children, ages 10.5 and 2 y when first seen by us, therapy with a low cholesterol, low saturated fat diet (20) had already been initiated. A diet comparable to the National Cholesterol Education Program Step 1 diet had been used, providing $<200 \mathrm{mg}$ cholesterol per d, and a polyunsaturated/ saturated ratio of $1(20)$. Because diet alone and, in the boy, diet plus subsequent colestipol $(7.5 \mathrm{~g} / \mathrm{d})$ were ineffective, with progressively severe elevations of total cholesterol and LDLC, slowly increasing hepatosplenomegaly, and increasingly abnormal liver 
function tests, the following prospective lovastatin treatment protocol was initiated. This protocol was approved by the Jewish Hospital Institutional Review Committee and was carried out with signed, informed, parental consent.

While continuing on diet (20), both children were to be started on lovastatin $20 \mathrm{mg}$, given with the evening meal. Lovastatin therapy was not initiated in the proband's sister until age 5, by which time we had accrued extensive data in her brother indicating that the therapy was well tolerated and safe. There were no adverse changes in liver function tests and CPK; normal accretion of height and weight were maintained.

Before lovastatin therapy, a slit lamp examination was carried out to obtain a baseline assessment of any preexisting lenticular opacities; none were found. After starting lovastatin, the children were scheduled for serial follow-up visits every 6-8 wk in our outpatient Cholesterol Center. At each visit after a 12-h fast, plasma total cholesterol, HDLC, LDLC, and triglycerides were measured (15-18) along with CPK, blood sugar, uric acid, and tests of renal and hepatic function. At each visit, the children's height, weight, and blood pressure were measured, a brief interval history was obtained, and a physical examination was performed.

The targeted goals in the two children were to reduce LDLC below the 75 th percentile $(2.84 \mathrm{mmol} / \mathrm{L})$ and to increase HDLC above the 10 th percentile $(1.03 \mathrm{mmol} / \mathrm{L})(21)$. If after $6 \mathrm{mo}$ of therapy with lovastatin $20 \mathrm{mg}$ these goals had not been achieved, the dose of lovastatin would be increased in the male proband to $40 \mathrm{mg} / \mathrm{d}$, the same dose successfully used by Ginsberg et al. (1).

To provide clinical semiquantitation of the degree of hepatosplenomegaly, upper and lower margins of liver and spleen were percussed at each visit, and the liver span in its longest plane was measured. Sonograms of liver and spleen to objectively measure organ size were obtained when the proband had been on lovastatin for 18,31 , and 44 mo. Liver and spleen sonograms were done in the proband's sister with the first measurement on diet only and the second after 22 mo on lovastatin. The radiologist reading the serial sonograms was blinded as to the children's lipid levels and clinical course.

The proband and his sister have been followed at the Jewish Hospital Cholesterol Center from July 2, 1987 through the present.

Statistical methods. In the proband, plasma lipid and lipoprotein cholesterol values, liver function tests, and CPKs for three baseline visits on diet alone, encompassing approximately 6 mo, were compared with values from serial groups of three outpatient follow-up visits encompassing periods of 4 to 6 mo sequentially during lovastatin treatment (Table 1). In the proband's sister, data from 14 baseline visits on diet alone, encompassing $35 \mathrm{mo}$, were compared with values from serial groups of three outpatient follow-up visits encompassing periods of 4 to 6 mo sequentially during lovastatin treatment (Table 2). Because the data were normally distributed, one-way analysis of variance was performed (22), comparing levels pre- and posttherapy; population marginal means were used if the analysis of variance $F$ value indicated significant $(p \leq 0.05)$ differences between any baseline or treatment periods.

\section{RESULTS}

Initial Evaluation of Family, Proband, and His Sister. Family. Fasting plasma total cholesterol, triglyceride, HDLC, and LDLC in the proband's parents, sister with CESD, and a second sister without CESD are displayed in Table 3 . The mother was entirely normal. The father had slightly elevated LDLC $(>75$ th percentile) (21); the sister without CESD had high LDLC (>90th percentile) (21), but her LDLC was much lower than her siblings' (Tables 1 and 2).

Proband. When first seen at the Jewish Hospital Cholesterol Center at age $10.5 \mathrm{y}$, the proband had been following a low cholesterol, low saturated fat diet $(20)$ for approximately 3 y. He was then in the 5th grade of school, habitually getting Cs and Ds, and said by his teachers to be an intelligent but inattentive student. Physical examination revealed hepatosplenomegaly (23) with the liver $12 \mathrm{~cm}$ in its longest plane and the spleen $5 \mathrm{~cm}$ below the left costal margin. Plasma total cholesterol was 6.18 , triglyceride 1.35, HDLC 0.96, and LDLC $4.6 \mathrm{mmol} / \mathrm{L}$.

Proband's sister. The proband's sister was first evaluated at the Cholesterol Center at age $2 \mathrm{y}$. She had hepatomegaly (23) with the liver span being $7 \mathrm{~cm}$, the liver percussed $4 \mathrm{~cm}$ below the right costal margin. Like her brother, she had been following a low cholesterol, low saturated fat diet (20). Plasma total cholesterol was 7.44, triglyceride 1.30, HDLC 0.62, and LDLC 6.23 $\mathrm{mmol} / \mathrm{L}$.

Response to lipid-lowering therapy. Proband. On diet and colestipol $7.5 \mathrm{~g} / \mathrm{d}$, the most that the proband could or would tolerate, plasma total cholesterol ranged from 7.03 to 8.02 , triglyceride from 1.28 to 1.67 , HDLC from 0.98 to 1.29 , and LDLC from 5.28 to $6.18 \mathrm{mmol} / \mathrm{L}$. Because there was no improvement in total cholesterol or LDLC or reduction of hepatosplenomegaly over the colestipol treatment period of $8 \mathrm{mo}$, colestipol was discontinued (Table 1, Fig. 1). Diet alone was maintained for the next 6 mo, with plasma total cholestero subsequently ranging from 7.16 to $7.58 \mathrm{mmol} / \mathrm{L}$, triglyceride from 1.19 to 1.99 , HDLC from 0.93 to 1.09 , and LDLC from 5.48 to $5.82 \mathrm{mg} / \mathrm{dL}$. Mean TC and LDLC on colestipol, 7.49 and $5.66 \mathrm{mmol} / \mathrm{L}$, respectively, did not differ from levels on diet alone, 7.40 and $5.68 \mathrm{mmol} / \mathrm{L}(p>0.7)$ (Table 1, Fig. 1).

In September 1988, when the patient was age $11.6 \mathrm{y}$, lovastatin $10 \mathrm{mg} / \mathrm{d}$ was started. As the lovastatin dose was increased in a stepwise fashion up to $40 \mathrm{mg} / \mathrm{d}$, approximately $1.1 \mathrm{mg} / \mathrm{kg}$, plasma total cholesterol fell significantly $(p \leq 0.025)$ and subsequently remained much lower $(p \leq 0.001)$ on lovastatin treatment than on diet only at baseline (Table 1, Fig. 1). Marked, progressively increasing reductions were observed for LDLC on lovastatin (Table 1, Fig. 1). Despite serial decrements in the lovastatin dose from 1.1 to 0.94 and $0.85 \mathrm{mg} / \mathrm{kg}$ (fixed dose of $40 \mathrm{mg} / \mathrm{d}$, with normal weight gain), significant reductions ( $p \leq$ 0.001 ) in plasma total cholesterol and LDLC were maintained (Table 1, Fig. 1). Mean total cholesterol and LDLC, 7.4 and 5.68 $\mathrm{mmol} / \mathrm{L}$ on diet alone, fell $30 \%$ to $5.2(p \leq 0.001)$ and $31 \%$ to $3.9 \mathrm{mmol} / \mathrm{L}(p \leq 0.001)$, respectively, by the last treatment period on lovastatin (Table 1, Fig. 1). Triglycerides fell slightly but not significantly on lovastatin (Table 1). Over time, mean HDLC levels fell gradually but not significantly (Table 1), being $0.99 \mathrm{mmol} / \mathrm{L}$ on diet alone and $0.93,1.0$, and $0.88 \mathrm{mmol} / \mathrm{L}$ in the last three lovastatin treatment periods. This decrease in HDLC was characteristic of the gradual fall in HDLC seen in adolescent males during sexual maturation (24) (Table 1).

Proband's sister. Before initiating lovastatin therapy, on diet alone, mean plasma total cholesterol was 8.01, LDLC 6.29, HDLC 0.65 , and triglyceride $2.34 \mathrm{mmol} / \mathrm{L}$ (Table 2). She completed 18 mo on lovastatin therapy, with mean cholesterol falling in the last treatment period to $7.05 \mathrm{mmol} / \mathrm{L}$ (12\%) (Table 2, Fig. 2). On lovastatin in the next to last treatment period, LDLC fell $20 \%$ from baseline to $5.03 \mathrm{mmol} / \mathrm{L}$ (Table 2). Her lovastatin dose (approximately $1.2 \mathrm{mg} / \mathrm{kg}$ ), was higher than that of her brother (approximately $1.1 \mathrm{mg} / \mathrm{kg}$ ), who nevertheless had more marked cholesterol lowering (Fig. 1, Tables 1 and 2). On lovastatin, her triglycerides fell, but not significantly, and HDLC also did not change significantly (Table 2 ).

Liver function tests and CPK on lovastatin therapy. In the proband, when lovastatin was started, at mo 20 there were transitory, significant increments in SGPT $(p \leq 0.01)$ and GGT $(p \leq 0.001)$ (Table 1$)$. Over the ensuing 34 mo of lovastatin therapy, SGPT and serum glutamic-oxaloacetic transaminase then fell to pretreatment baseline and below (Table 1). On lovastatin $40 \mathrm{mg}, 1.13 \mathrm{mg} / \mathrm{kg}$ falling to $0.85 \mathrm{mg} / \mathrm{kg}$, there was a slow, gradual, significant increase in GGT, with acceptable values well below the "high" cutpoint set by the Federal Drug Administration (three times the upper normal limit) (Table 1). 
Table 1. Mean $(S D)$ liver function tests $(U / L), C P K(U / L)$, lipids, and lipoprotein cholesterols (mmol/L) in proband before and during 40 mo on lovastatin*

\begin{tabular}{|c|c|c|c|c|c|c|c|c|c|}
\hline $\begin{array}{c}\text { Cumulative mo } \\
\text { of treatment }\end{array}$ & $\begin{array}{c}\text { Treatment } \\
\text { period }\end{array}$ & GGT & SGOT & SGPT & $\mathrm{CPK}$ & $\mathrm{TC}$ & TG & HDLC & LDLC \\
\hline ANOVA $(F)$ & & $9.8+$ & $2.6 \neq$ & $4.8 \S$ & 0.3 & $10.4 \dagger$ & 1.6 & 1.6 & $7.0 \dagger$ \\
\hline $8 \|$ & 1 & & & & & $\begin{array}{c}7.49 \\
(0.49)\end{array}$ & $\begin{array}{c}1.47 \\
(0.20)\end{array}$ & $\begin{array}{c}1.14 \\
(0.16)\end{array}$ & $\begin{array}{c}5.66 \\
(0.47)\end{array}$ \\
\hline $14 \pi$ & 2 & $\begin{array}{l}11 \\
(1.5)\end{array}$ & $\begin{array}{l}44 \\
(7.6)\end{array}$ & $\begin{array}{l}44 \\
(4.2)\end{array}$ & $\begin{array}{l}186 \\
(53.0)\end{array}$ & $\begin{array}{c}7.40 \\
(0.21)\end{array}$ & $\begin{array}{c}1.58 \\
(0.40)\end{array}$ & $\begin{array}{c}0.99 \\
(0.08)\end{array}$ & $\begin{array}{c}5.68 \\
(0.18)\end{array}$ \\
\hline $20^{* *}$ & 3 & $\begin{array}{l}20 \dagger \\
(2)\end{array}$ & $\begin{array}{l}48 \\
(9.7)\end{array}$ & $\begin{array}{l}62 \S \\
(11)\end{array}$ & $\begin{array}{l}142 \\
(64.6)\end{array}$ & $\begin{array}{c}7.39 \\
(0.16)\end{array}$ & $\begin{array}{c}1.22 \\
(0.18)\end{array}$ & $\begin{array}{c}1.14 \\
(0.03)\end{array}$ & $\begin{array}{c}5.69 \\
(0.23)\end{array}$ \\
\hline $23^{* *}$ & 4 & $\begin{array}{l}15 \ddagger \\
(2.5)\end{array}$ & $\begin{array}{l}40 \\
(3.0)\end{array}$ & $\begin{array}{l}53 \\
(6.2)\end{array}$ & $\begin{array}{l}163 \\
(86.3)\end{array}$ & $\begin{array}{r}6.60 \ddagger \\
(0.63)\end{array}$ & $\begin{array}{c}1.55 \\
(0.38)\end{array}$ & $\begin{array}{c}0.96 \\
(0.12)\end{array}$ & $\begin{array}{c}4.94 \\
(0.58)\end{array}$ \\
\hline $27 \dagger \dagger$ & 5 & $\begin{array}{l}16 \\
(2)\end{array}$ & $\begin{array}{l}48 \\
(2.1)\end{array}$ & $\begin{array}{l}52 \\
(7.8)\end{array}$ & $\begin{array}{l}182 \\
(22.6)\end{array}$ & $\begin{array}{l}6.39+7 \\
(0.47)\end{array}$ & $\begin{array}{c}1.62 \\
(0.74)\end{array}$ & $\begin{array}{c}0.97 \\
(0.20)\end{array}$ & $\begin{array}{l}4.66 \text { 㧊 } \\
(0.51)\end{array}$ \\
\hline $31+t$ & 6 & $\begin{array}{l}16 \ddagger \\
(1.5)\end{array}$ & $\begin{array}{l}36 \\
(4.0)\end{array}$ & $\begin{array}{l}48 \\
(9.7)\end{array}$ & $\begin{array}{l}197 \\
(76.4)\end{array}$ & $\begin{array}{c}5.94 \dagger \\
(0.44)\end{array}$ & $\begin{array}{c}1.23 \\
(0.14)\end{array}$ & $\begin{array}{c}1.09 \\
(0.08)\end{array}$ & $\begin{array}{c}4.29 \S \\
(0.34)\end{array}$ \\
\hline $37 \dagger \dagger$ & 7 & $\begin{array}{l}17 \S \\
(1.5)\end{array}$ & $\begin{array}{l}41 \\
(5.0)\end{array}$ & $\begin{array}{l}38 \\
(2.5)\end{array}$ & $\begin{array}{l}156 \\
(49.6)\end{array}$ & $\begin{array}{r}5.78 \dagger \\
(0.49)\end{array}$ & $\begin{array}{c}1.32 \\
(0.33)\end{array}$ & $\begin{array}{c}0.92 \\
(0.05)\end{array}$ & $\begin{array}{c}4.24 \dagger \\
(0.34)\end{array}$ \\
\hline $41 \dagger \dagger$ & 8 & $\begin{array}{l}18 \S \\
(2.3)\end{array}$ & $\begin{array}{l}42 \\
(0.6)\end{array}$ & $\begin{array}{l}43 \\
(3.2)\end{array}$ & $\begin{array}{l}151 \\
(43.8)\end{array}$ & $\begin{array}{c}5.64 \dagger \\
(0.24)\end{array}$ & $\begin{array}{c}1.10 \\
(0.15)\end{array}$ & $\begin{array}{c}0.97 \\
(0.10)\end{array}$ & $\begin{array}{c}4.18 \dagger \\
(0.27)\end{array}$ \\
\hline $45 \dagger \dagger$ & 9 & $\begin{array}{l}21 \dagger \\
(3.6)\end{array}$ & $\begin{array}{l}35 \\
(5.0)\end{array}$ & $\begin{array}{l}37 \\
(4.4)\end{array}$ & $\begin{array}{l}150 \\
(52.3)\end{array}$ & $\begin{array}{c}5.5 \dagger \\
(0.60)\end{array}$ & $\begin{array}{c}0.94 \\
(0.28)\end{array}$ & $\begin{array}{c}0.93 \\
(0.16)\end{array}$ & $\begin{array}{c}4.17 \dagger \\
(0.81)\end{array}$ \\
\hline $49 \uparrow \dagger$ & 10 & $\begin{array}{l}23 \dagger \\
(2.4)\end{array}$ & $\begin{array}{l}36 \\
(5.0)\end{array}$ & $\begin{array}{l}43 \\
(3.1)\end{array}$ & $\begin{array}{l}136 \\
(4.2)\end{array}$ & $\begin{array}{c}5.6 \dagger \\
(0.40)\end{array}$ & $\begin{array}{c}1.03 \\
(0.12)\end{array}$ & $\begin{array}{c}1.0 \\
(0.19)\end{array}$ & $\begin{array}{c}4.13 \dagger \\
(0.36)\end{array}$ \\
\hline $54 \dagger \dagger$ & 11 & $\begin{array}{l}25 \dagger \\
(1.7)\end{array}$ & $\begin{array}{l}34 \% \\
(1.5)\end{array}$ & $\begin{array}{l}39 \\
(3.5)\end{array}$ & $\begin{array}{l}188 \\
(70.4)\end{array}$ & $\begin{array}{c}5.2 \dagger \\
(0.40)\end{array}$ & $\begin{array}{c}1.03 \\
(0.21)\end{array}$ & $\begin{array}{c}0.88 \\
(0.05)\end{array}$ & $\begin{array}{r}3.90 \dagger \\
(0.50)\end{array}$ \\
\hline
\end{tabular}

* SGOT, serum glutamic-oxaloacetic transaminase; TC, total cholesterol; TG, triglyceride; ANOVA, analysis of variance.

$\dagger p<0.001$, values on diet only (treatment period 2) $v s$ other treatment periods.

$\$ p<0.05$, values on diet only $v s$ other treatment periods.

$\S p<0.01$, values on diet only $v s$ other treatment periods.

$\|$ Colestipol $7.5 \mathrm{~g} / \mathrm{d}$.

If Diet only.

** Lovastatin $30 \mathrm{mg} / \mathrm{d}$.

†† Lovastatin $40 \mathrm{mg} / \mathrm{d}$.

$\sharp \ddagger p<0.025$, values on diet only $v s$ other treatment periods.

Table 2. Mean (SD) liver function tests $(U / L), C P K(U / L)$, lipids, and lipoprotein cholesterols (mmol/L) in proband's sister before and during 18 mo on lovastatin*

\begin{tabular}{|c|c|c|c|c|c|c|c|c|c|}
\hline $\begin{array}{c}\text { Cumulative mo } \\
\text { of treatment }\end{array}$ & $\begin{array}{l}\text { Treatment } \\
\text { period }\end{array}$ & GGT & SGOT & SGPT & $\mathrm{CPK}$ & $\mathrm{TC}$ & $\mathrm{TG}$ & HDLC & LDLC \\
\hline ANOVA $(F)$ & & $15.4 \dagger$ & 0.77 & 0.68 & 1.0 & 1.74 & 1.39 & 0.90 & 1.43 \\
\hline 5 & 1 & & & & & $\begin{array}{c}8.15 \\
(1.18)\end{array}$ & $\begin{array}{c}1.96 \\
(1.05)\end{array}$ & $\begin{array}{c}0.54 \\
(0.11)\end{array}$ & $\begin{array}{c}6.71 \\
(1.38)\end{array}$ \\
\hline 12 & 2 & $\begin{array}{l}14 \\
(0.0)\end{array}$ & $\begin{array}{l}56 \\
(2.1)\end{array}$ & $\begin{array}{l}48 \\
(0.7)\end{array}$ & 143 & $\begin{array}{c}7.24 \\
(0.90)\end{array}$ & $\begin{array}{c}2.36 \\
(0.88)\end{array}$ & $\begin{array}{c}0.68 \\
(0.47)\end{array}$ & $\begin{array}{c}5.49 \\
(0.99)\end{array}$ \\
\hline 20 & 3 & & 64 & 48 & & $\begin{array}{c}8.24 \\
(0.83)\end{array}$ & $\begin{array}{c}2.23 \\
(0.40)\end{array}$ & $\begin{array}{c}0.59 \\
(0.10)\end{array}$ & $\begin{array}{c}6.64 \\
(0.79)\end{array}$ \\
\hline 28 & 4 & 9 & 49 & 37 & 105 & $\begin{array}{c}7.68 \\
(0.73)\end{array}$ & $\begin{array}{c}2.99 \\
(1.60)\end{array}$ & $\begin{array}{c}0.67 \\
(0.07)\end{array}$ & $\begin{array}{c}5.64 \\
(1.39)\end{array}$ \\
\hline 35 & 5 & $\begin{array}{l}14 \\
(1.0)\end{array}$ & $\begin{array}{l}43 \\
(17.0)\end{array}$ & $\begin{array}{l}43 \\
(12.7)\end{array}$ & $\begin{array}{l}141 \\
(37.7)\end{array}$ & $\begin{array}{c}8.63 \\
(0.35)\end{array}$ & $\begin{array}{c}2.41 \\
(0.36)\end{array}$ & $\begin{array}{c}0.79 \\
(0.04)\end{array}$ & $\begin{array}{c}6.73 \\
(0.15)\end{array}$ \\
\hline Pooled baseline & & $\begin{array}{l}13 \\
(2.1)\end{array}$ & $\begin{array}{c}50 \\
(12.9)\end{array}$ & $\begin{array}{l}44 \\
(8.3)\end{array}$ & $\begin{array}{l}134 \\
(31.3)\end{array}$ & $\begin{array}{c}8.01 \\
(0.87)\end{array}$ & $\begin{array}{c}2.34 \\
(0.80)\end{array}$ & $\begin{array}{c}0.65 \\
(0.22)\end{array}$ & $\begin{array}{c}6.29 \\
(1.01)\end{array}$ \\
\hline $39 \ddagger$ & 6 & $\begin{array}{l}14 \\
(1.0)\end{array}$ & $\begin{array}{l}49 \\
(8.3)\end{array}$ & $\begin{array}{l}37 \\
(7.1)\end{array}$ & $\begin{array}{c}80 \\
(49.4)\end{array}$ & $\begin{array}{c}7.62 \\
(0.37)\end{array}$ & $\begin{array}{l}1.60 \\
(0.57)\end{array}$ & $\begin{array}{c}0.78 \\
(0.28)\end{array}$ & $\begin{array}{c}6.10 \\
(0.29)\end{array}$ \\
\hline $43 \ddagger$ & 7 & $\begin{array}{l}16 \\
(0.0)\end{array}$ & $\begin{array}{l}41 \\
(4.2)\end{array}$ & $\begin{array}{l}36 \\
(2.1)\end{array}$ & $\begin{array}{l}117 \\
(37.8)\end{array}$ & $\begin{array}{l}7.71 \\
(0.96)\end{array}$ & $\begin{array}{c}1.38 \\
(0.53)\end{array}$ & $\begin{array}{c}0.87 \\
(0.13)\end{array}$ & $\begin{array}{c}6.21 \\
(0.78)\end{array}$ \\
\hline $47 \ddagger$ & 8 & $\begin{array}{l}18 \S \\
(2.1)\end{array}$ & $\begin{array}{l}46 \\
(4.6)\end{array}$ & $\begin{array}{l}36 \\
(4.0)\end{array}$ & $\begin{array}{l}122 \\
(31.8)\end{array}$ & $\begin{array}{c}6.72 \\
(0.60)\end{array}$ & $\begin{array}{c}1.84 \\
(0.43)\end{array}$ & $\begin{array}{c}0.84 \\
(0.14)\end{array}$ & $\begin{array}{c}5.03 \\
(0.61)\end{array}$ \\
\hline $54+$ & 9 & $\begin{array}{l}20 \dagger \\
(1.2)\end{array}$ & $\begin{array}{l}53 \\
(10.8)\end{array}$ & $\begin{array}{c}46 \\
(12.9) \\
\end{array}$ & $\begin{array}{l}202 \\
(90.1)\end{array}$ & $\begin{array}{l}7.05 \\
(0.34)\end{array}$ & $\begin{array}{c}1.40 \\
(0.24)\end{array}$ & $\begin{array}{c}0.78 \\
(0.03)\end{array}$ & $\begin{array}{c}5.63 \\
(0.47)\end{array}$ \\
\hline
\end{tabular}

* SGOT, serum glutamic-oxaloacetic transaminase; TC, total cholesterol; TG, triglyceride; ANOVA, analysis of variance.

$\dagger p<0.001$, values for pooled baseline (treatment periods 1-5) vs other treatment periods.

$\ddagger$ Lovastatin $20 \mathrm{mg} / \mathrm{d}$.

$\S p<0.01$, values for pooled baseline $v s$ other treatment periods. 
Table 3. Lipids and lipoprotein cholesterols $(\mathrm{mmol} / \mathrm{L})$ in kindred

\begin{tabular}{lccccc}
\hline & Age $(\mathrm{y})$ & TC & TG & HDLC & LDLC \\
\hline Mother & 37.7 & 5.22 & 1.34 & 1.14 & 3.46 \\
Father & 46 & 5.69 & 1.31 & 1.03 & 4.06 \\
Sister without CESD & 8.5 & 5.07 & 0.56 & 1.53 & 3.28 \\
Proband & 10.5 & 6.18 & 1.35 & 0.96 & 4.60 \\
Sister with CESD & 2 & 7.44 & 1.30 & 0.62 & 6.23 \\
\hline
\end{tabular}

In the proband's sister, there was a slow, progressive increase in GGT during lovastatin therapy similar to that observed in her brother (again with acceptable values), whereas serum glutamicoxaloacetic transaminase and SGPT oscillated up and down and did not differ significantly from pretreatment levels (Table 2).

There was no significant change in CPK on lovastatin therapy in the proband over time, when compared to baseline levels (Table 1). In his sister, CPK levels also revealed no significant increase on lovastatin therapy (Table 2). The CPK levels at mo 54 in the proband and in his sister were not significantly higher when compared to baseline levels (Tables 1 and 2), nor did they differ from levels at mo 49 and 47 , respectively. At no time during lovastatin treatment in either the proband or his sister were there episodes of significant muscle tenderness or myositis.

Accretion of Height and Weight. Figure 3 summarizes accretion of height and weight in the proband, plotted against population 5th, 10th, 25th, and 50th percentiles (25). From age 7 to $11.7 \mathrm{y}$, before lovastatin, height varied between the 25 th and 50 th percentiles. On lovastatin therapy, the pattern of accretion of height was comparable to that before therapy, with height first varying around the 25 th percentile, and then rising to the 25th to 50 th percentile level range (Fig. 3). There was no diminution in accretion of height on lovastatin therapy over the $3.3 \mathrm{y}$ followup period from age 11.7 to 15 y (Fig. 3).
At the proband's first visit to the Cholesterol Center, weight was about the 25 th percentile (Fig. 3). On lovastatin therapy, weight initially appeared to fall, riding along the 10 th percentile line until age 15 when it rose back above the 25 th percentile (Fig. 3). Overall, the pattern of accretion of weight on lovastatin was not different from that before lovastatin, particularly because at ages $5-7$, very similar to ages $12-14$, weight had fallen from the 25 th down to about the 10th percentile and then risen (Fig. $3)$.

For the proband's sister, on diet alone from ages 2 to $5 \mathrm{y}$, height was maintained close to the 50th percentile range (Fig. 4). On lovastatin, the height rank initially fell to the 25 th percentile and then rose to between the 25th and 50th percentiles (Fig. 4). Weight was maintained at about the 10 th-25th percentile on diet alone and was in the same range on diet plus lovastatin (Fig. 4).

Changes in liver and spleen size on cholesterol-lowering therapy. Proband. At the end of colestipol therapy, the liver was percussed $6 \mathrm{~cm}$ below the right costal margin (with a span of 12 $\mathrm{cm}$ in the midclavicular line) and the spleen was palpated $5 \mathrm{~cm}$ below the left costal margin. On lovastatin $40 \mathrm{mg}$, hepatomegaly progressively resolved. Five mo after starting $40 \mathrm{mg} / \mathrm{d}$, the liver was percussed at $5 \mathrm{~cm}$ below the right costal margin, 2 mo later at $3 \mathrm{~cm}$ below, and 3 mo later at $1.7 \mathrm{~cm}$ below. One y after initiation of lovastatin, at age $12.7 \mathrm{y}$, the total length of liver dullness was $9 \mathrm{~cm}(v s 12 \mathrm{~cm}$ at age $10.7 \mathrm{y})$, and the liver could not be percussed below the right costal margin. Subsequently, the liver size has remained generally stable, about $8-9 \mathrm{~cm}$, much smaller than pretreatment $(12 \mathrm{~cm})$.

Using the formula in Behrman et al. (23) for the expected span of liver dullness in the midclavicular line, when, at age 12.7 $y$, the proband's actual liver span was $9 \mathrm{~cm}$, the expected span would have been $5.12 \mathrm{~cm}$; subsequently, throughout the remainder of follow-up, when his actual liver span was $8-9 \mathrm{~cm}$, the
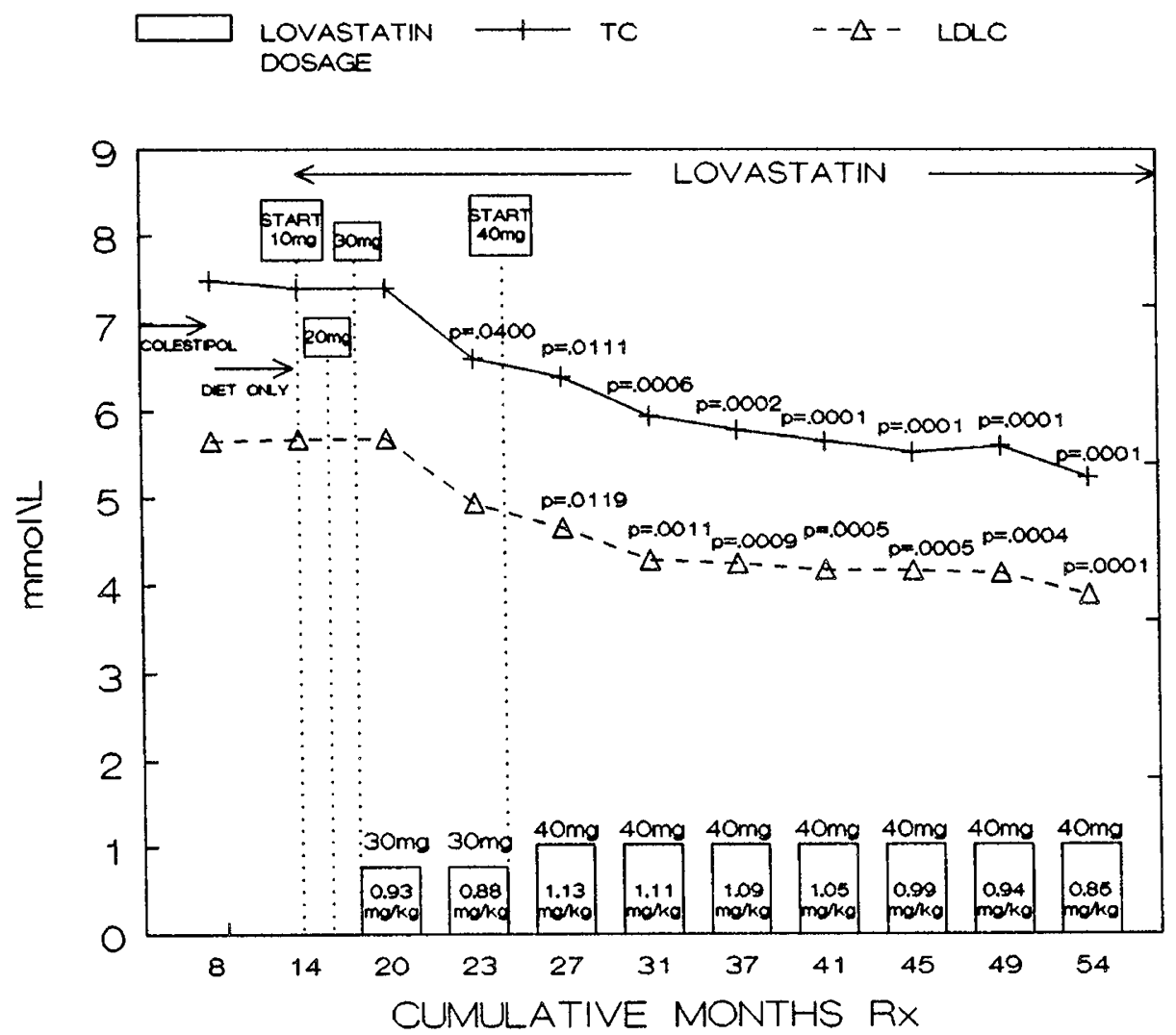

Fig. 1. Mean plasma total cholesterol $(T C)$ and LDLC $(\mathrm{mmol} / \mathrm{L})$ in the male proband before and during 40 mo on lovastatin treatment. Values on lovastatin compared to baseline on diet alone. 


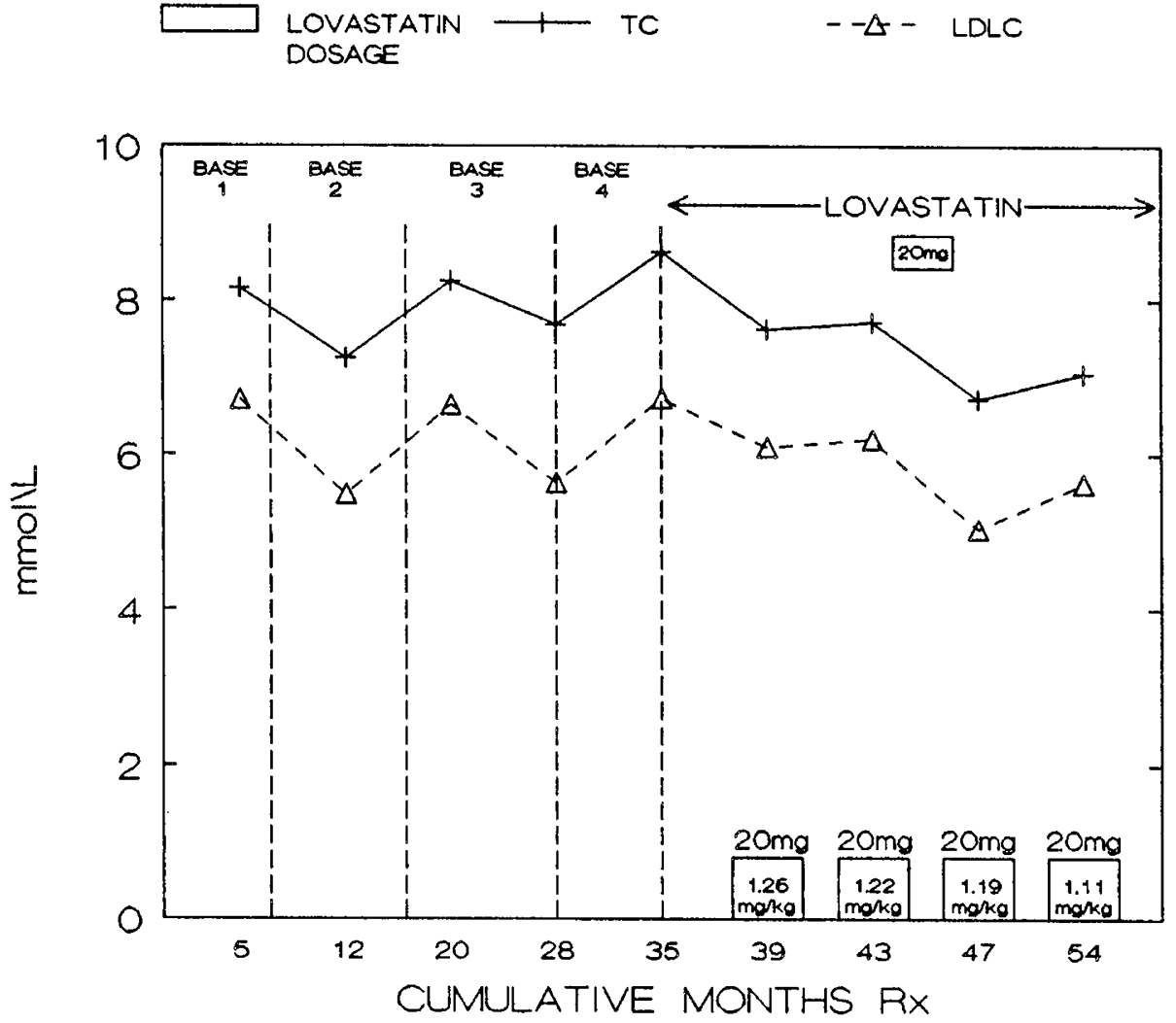

Fig. 2. Mean plasma total cholesterol $(T C)$ and LDLC (mmol/L) in the female child before and during 18 mo on lovastatin treatment. Values on lovastatin compared to baseline on diet alone.

A

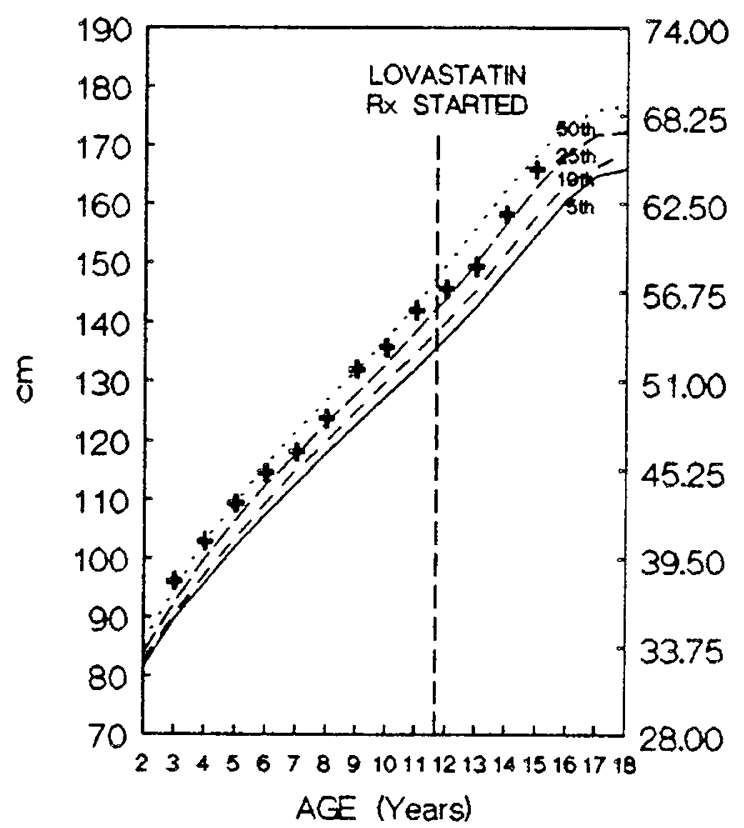

B

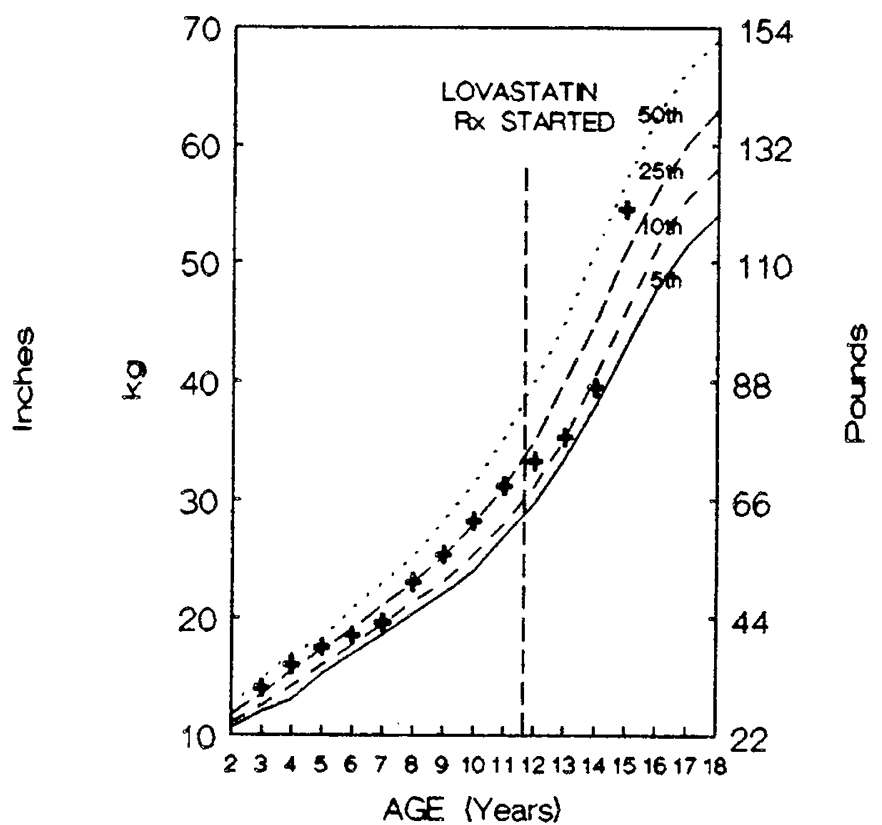

Fig. 3. A, Accretion of height over time in the male proband $(+)$ plotted against population 5 th, 10 th, 25 th, and 50 th percentiles. $B$, Accretion of weight over time in the male proband $(+)$ plotted against population 5th, 10th, 25th, and 50th percentiles. Adapted from National Center for Health Statistics (25).

expected span would have ranged from $5.3 \mathrm{~cm}$ at 12.8 y to 7.4 $\mathrm{cm}$ at age $15 \mathrm{y}$. Thus, by age 15 , his liver size was only moderately above that expected.

After 15 mo of lovastatin therapy, the spleen, which initially had been palpated $5 \mathrm{~cm}$ below the left costal margin, could not be palpated. Subsequently, the spleen has not been palpable below the left costal margin.

Liver and spleen sonograms were done at 32,45 , and $58 \mathrm{mo}$, with the proband on lovastatin for 18,31 , and $44 \mathrm{mo}$, respectively. The liver's cephalocaudal distance fell from $18.5 \mathrm{~cm}$ at 32 
A

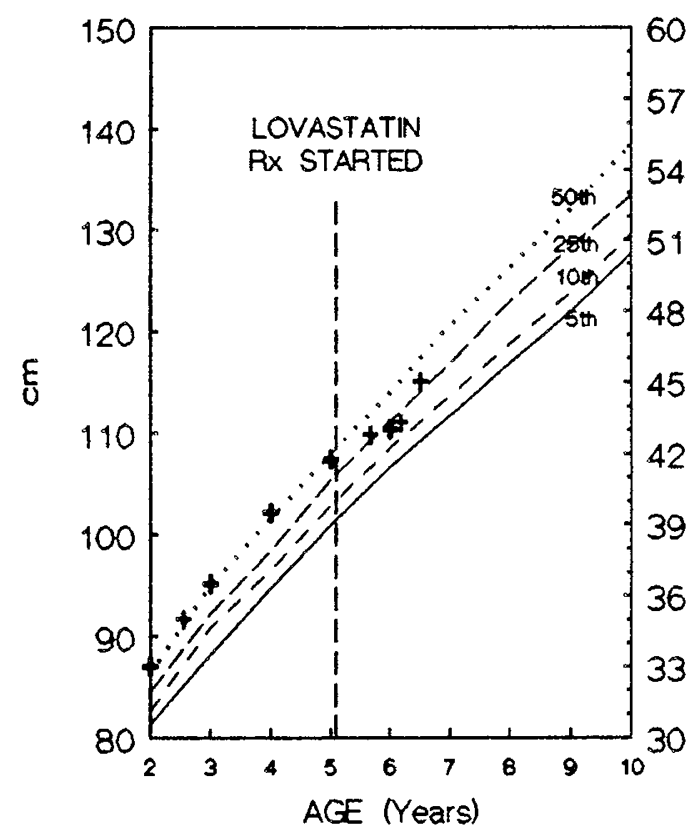

B

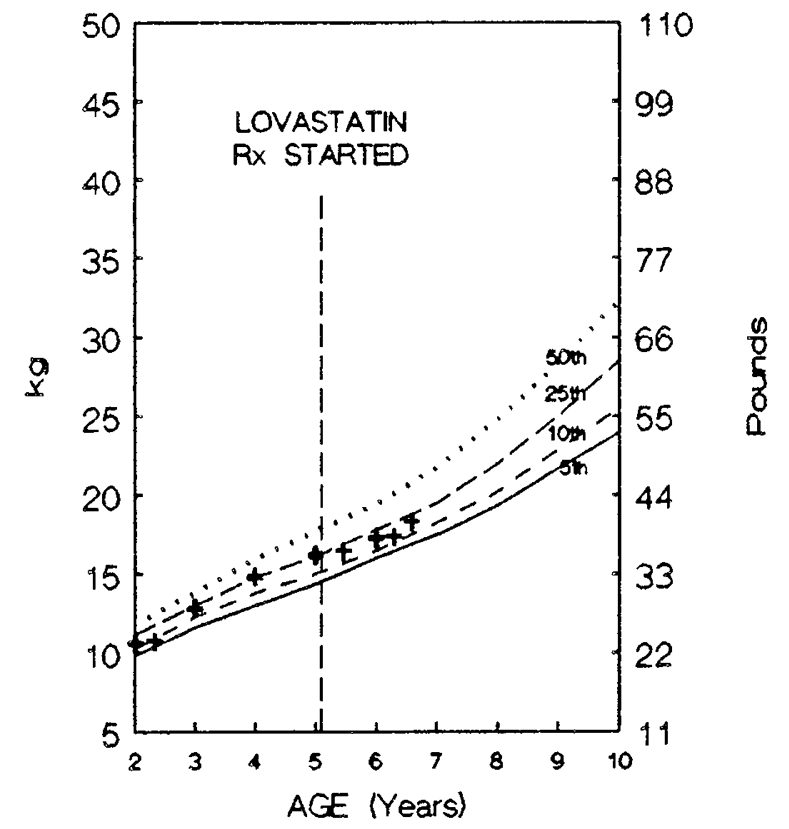

Fig. 4. A, Accretion of height over time in the female child $(+)$ plotted against population 5 th, 10 th, 25 th, and 50 th percentiles. $B$, Accretion of weight over time in the female child $(+)$ plotted against population 5 th, 10th, 25 th, and 50 th percentiles. Adapted from National Center for Health Statistics (25).

mo follow-up to $15.5 \mathrm{~cm}$ at $45 \mathrm{mo}$ and to $11.2 \mathrm{~cm}$ at $58 \mathrm{mo}$. Spleen length fell from $11.3 \mathrm{~cm}$ to 10.5 and then $10.0 \mathrm{~cm}$ at the three measurements. Thus, on lovastatin therapy in the proband, there was reduction in both liver and spleen size.

Proband's sister. When first seen at age $2 \mathrm{y}$, the female child had hepatomegaly, with the liver span percussed at $7 \mathrm{~cm}, 4 \mathrm{~cm}$ below the right costal margin. On diet alone, at ages 2.5, 3.1, 4, and $5 \mathrm{y}$, the liver size increased, with the liver span being percussed at $7.5,8.5,7$, and $10 \mathrm{~cm}$, respectively. Having been on lovastatin for $6 \mathrm{mo}$, at age 5.6 y the liver span was again larger, at $12 \mathrm{~cm}$, and it was $13 \mathrm{~cm}$ at age 6 . However, at age 6.5 , having been on lovastatin for $1.5 \mathrm{y}$, the liver span was markedly reduced to $9.5 \mathrm{~cm}$. The expected span of liver dullness is 6.0 to $6.5 \mathrm{~cm}$ in females by age $12 \mathrm{y}(23)$.

Liver and spleen sonograms were done on the proband's sister at 32 and 58 mo follow-up, with the first sonogram on diet only and the second after 22 mo on lovastatin. The liver's cephalocaudal distance fell from $13.5 \mathrm{~cm}$ at $32 \mathrm{mo}$ to $12 \mathrm{~cm}$ at $58 \mathrm{mo}$, with spleen length falling slightly from 8.8 to $8.5 \mathrm{~cm}$. Thus, on lovastatin therapy in the proband's sister, there was reduction in liver and spleen size as judged by the sonogram.

Repeat slit-lamp examinations of the lens have been normal in both children on lovastatin.

Unusual clinical events. Having been on lovastatin $40 \mathrm{mg}$ for about $6 \mathrm{wk}$, and probably associated with glue sniffing with a neighbor, the proband sustained a single, left-sided, grand mal seizure. Skull films, magnetic resonance imaging scan, and serial EEG were negative; no anticonvulsants were prescribed. There have been no recurrences.

\section{DISCUSSION}

In hypercholesterolemic adults, therapy with lovastatin has been safe $(26,27)$, with changes in liver function tests occurring in less than $1.5 \%$ of patients. Moreover, subsequent to the EXCEL publication (27), the lovastatin package insert has been revised to no longer require serial slit-lamp exams to rule out cataract development, reflecting the absence of lenticular opacities attributable to lovastatin therapy.
Lovastatin, when administered in a dosage of $40 \mathrm{mg} / \mathrm{d}(1.1$ $\mathrm{mg} / \mathrm{kg} / \mathrm{d}$ ) for $3.3 \mathrm{y}$, significantly reduced plasma total cholesterol and LDLC in a 15 -y-old male proband with CESD. Improvement in these values was noted in the proband's 5 -y-old sister after she received lovastatin at a dosage of $20 \mathrm{mg} / \mathrm{d}(1.2 \mathrm{mg} / \mathrm{kg} / \mathrm{d})$ for 1.5 $\mathrm{y}$, but it did not reach statistical significance. In both children, marked reduction in hepatosplenomegaly was documented on lovastatin therapy.

Lovastatin treatment was well tolerated in both children. Accretion in height and weight proceeded normally along previously established pretreatment growth percentiles. Congruent with previous reports $(1,10-12)$ there were no adverse changes in liver function tests, increases in CPK, or lenticular changes.

There is a possibility that reductase inhibition by lovastatin, with the attendant up-regulation of LDL receptors, could cause greater cholesteryl ester accumulation in the liver. In our patients, this outcome was very unlikely, given resolution of hepatosplenomegaly on lovastatin therapy. Ginsberg et al. (1) found no significant change in cholesteryl ester accumulation in the liver after $8 \mathrm{mo}$ of treatment of CESD with lovastatin $40 \mathrm{mg} / \mathrm{d}$ in a 9 -y-old girl. Tarantino et al. (10) reported that lovastatin $(20$ $\mathrm{mg} / \mathrm{d}$ ) for 6 mo decreased liver cholesteryl ester by $13 \%$ in CESD.

To the extent that lovastatin reduces endogenous cholesterol biosynthesis (1), because most of the cholesteryl ester in the hepatic lysosomes comes from cholesterol esterified in the blood, lovastatin should reduce the amount of cholesteryl ester returning to the liver and should also reduce LDLC levels. Our findings over treatment periods of 3.3 and $1.5 \mathrm{y}$ are congruent with those of Tarantino et al. (10). In two sisters with CESD (ages 4 and 17 y), Tarantino et al. gave lovastatin $20 \mathrm{mg}$ for $6 \mathrm{mo}$ and reported marked decreases in plasma cholesterol, triglyceride, and LDLC, with increases in HDLC. On lovastatin therapy, there was also a significant increase in linear attenuation on hepatic computed tomography scanning, suggesting a decreased liver fat content (10). Tarantino et al. also reported that, 6 mo after lovastatin therapy was initiated, liver tissue obtained by biopsy had $13 \%$ less esterified cholesterol than before treatment and concluded that "... lovastatin may be effective in treating children with 
cholesterol-ester storage disease" (10). McCoy and Yokoyama (11) recently reported treatment of a 13-y-old boy with CESD with combined cholestyramine and lovastatin over a period of $1.5 \mathrm{y}$. There was a decrease in LDLC and an increase in HDLC attributed to lovastatin therapy; liver and spleen size were reduced during therapy, as judged by physical examination. In contrast to the successful treatment of pediatric CESD reported by Tarantino et al. (10) and McCoy and Yokoyama (11), DiBisceglie et al. (12) treated three children with CESD with lovastatin $40 \mathrm{mg} / \mathrm{d}$ for at least $12 \mathrm{mo}$ and observed no significant changes in serum lipoprotein concentrations or liver histopathology after therapy. It is not clear why lovastatin was effective in our current study, although more so in the proband than his sister, and in those of Tarantino et al. (10) and McCoy et al. (11) but not in the report of Di-Bisceglie et al. (12). A concomitant hyperlipidemia, inherited separately, might explain some of the differences in lipid levels in patients with CESD. As noted by Tarantino et al. (10) “. ... this finding may be explained by heterogeneity of response to the lovastatin or by underlying differences in the factors responsible for the hyperlipidemia in CESD." Within this frame of reference, our proband's father and a second sister (without CESD) had moderately elevated LDLC. In agreement with the findings of Ginsburg et al. (1) and others $(10,11)$, we conclude that lovastatin is a safe and effective treatment for CESD in children, in both ameliorating hyperlipidemia and resolving hepatosplenomegaly.

Because lovastatin has not yet been approved for general clinical pediatric use, there is currently limited data on its safety and efficacy in children with heterozygous and homozygous forms of familial hypercholesterolemia $(28-32)$. However, no major side effects have resulted from its use in children with familial hypercholesterolemia (28-32). Based on our and other's $(1,10-12)$ experience with safety and efficacy of lovastatin in children with CESD, we speculate that ongoing controlled clinical trials in children with severe heterozygous familial hypercholesterolemia will demonstrate that lovastatin is not only more effective therapeutically than currently approved treatment alternatives (bile acid binding resins) but also safely produces these effects without interfering with normal growth and development.

\section{REFERENCES}

1. Ginsberg HN, Le NA, Short PM, Ramakrishnan R, Desnick RJ 1987 Suppression of apolipoprotein B production during treatment of cholesteryl ester storage disease with lovastatin. J Clin Invest 80:1692-1697

2. Schmitz G, Assman G 1989 Acid lipase deficiency: Wolman disease and cholesteryl ester storage disease. In: Scriber CR, Beaudet AL, Sly WS, Valle $\mathrm{D}$ (eds) The Metabolic Basis of Inherited Diseases. McGraw-Hill Book Co, New York, pp 1623-1644

3. Kelly DR, Hoeg J, Demosky JD, Brewer Jr HB 1985 Characterization of plasma lipids and lipoproteins in cholesteryl ester storage disease. Biochem Med 33:29-37

4. Kostner GM. Hadorn B, Roscher A, Zechner R 1985 Plasma lipids and lipoproteins of a patient with cholesteryl ester storage disease. $\mathrm{J}$ Inherited Metab Dis 8:9-12

5. Schiff L, Schubert WK, McAdams AJ, Spiegel EL, O'Donnell JF 1988 Hepatic cholesterol ester storage disease: a familial disorder. I. Clinical aspects. Am J Med 44:538-546

6. D'Agostino D, Bay L, Gallo G, Chamoles N 1988 Cholesterol ester storage disease: clinical, biochemical, and pathological studies of four new cases. $J$ Pediatr Gastroenterol Nutr 7:446-450

7. Edelstein RA, Filling-Katz MR, Pentchev P, Gal A, Chamdra R, Shawker T, Guzzetta P 1988 Cholesteryl ester storage disease: a patient with massive splenomegaly and splenic abscess. Am J Gastroenterol 83:687-692
8. Tylki-zymanska A, Maciejko D, Wozniewica B, Muszynska B 1987 Two cases of cholesteryl ester storage disease (CESD) acid lipase deficiency. Hepatogastroenterol 34:98-99

9. Longhi R, Vergani C, Valsasina R, Riva E, Galluzzo C, Agostoni C, Giovannini M 1988 Cholesteryl ester storage disease: risk factors for atherosclerosis in a 15-year-old-boy. J Inherited Metab Dis 11:143-145

10. Tarantino MD, McNamara DJ, Granstrom P, Ellefson RD, Unger EC, Udall JN 1991 Lovastatin therapy for cholesterol ester storage disease in two sisters. J Pediatr 118:131-135

11. McCoy E, Yokoyama S 1991 Treatment of cholesteryl ester storage disease with combined cholestyramine and lovastatin. Ann NY Acad Sci 623: 453-454

12. Di-Bisceglie AM, Ishak KG, Rabin L, Hoeg JM 1990 Cholesteryl ester storage disease: hepatopathology and effects of therapy with lovastatin. Hepatology 11:764-772

13. Ferry GD, Whisennand HH, Finegold MH, Alpert E, Glombiciki A 1991 Liver transplantation for cholesteryl ester storage disease. Pediatr Gastroenterol Nutr 12:376-378

14. Pozanansky MH, Hutchison SK, Davis RJ 1989 Enzyme replacement therapy in fibroblasts from a patient with cholesteryl ester storage disease. FASEB $J$ 3:152-156

15. Allain C, Poon LS, Chan CSG, Richmond W, Fu PC 1974 Enzymatic determination of total serum cholesterol. Clin Chem 20:470-475

16. McGowan MW, Artiss JD, Strandbergh DR, Zak B 1983 A peroxidase-coupled method for the colorimetric determination of serum triglycerides. Clin Chem 29:538-543

17. Assman G, Schriewer H, Schmitz G, Hagele EO 1983 Quantification of high density lipoprotein cholesterol by precipitation with phosphotungstic acid/ $\mathrm{MgCl}_{2}$. Clin Chem 29:2026-2030

18. Friedwald WT, Levy RI, Fredrickson DS 1972 Estimation of the concentration of low density lipoprotein cholesterol in plasma without use of the preparative ultracentrifuge. Clin Chem 18:499-502

19. Myers GL, Cooper GR, Winn CL, Smith SJ 1989 The Centers for Disease Control: National Heart, Lung and Blood Institute Lipid Standardization Program. An approach to accurate and precise lipid measurements. Clin Lab Med 9:105-135

20. Report of the National Cholesterol Education Program expert panel on detection, evaluation, and treatment of high blood cholesterol in adults $1988 \mathrm{Arch}$ Int Med 148:36-69

21. The Prevalence Study 1980 The Lipid Research Clinics Population Studies Data Book. US Dept of Health and Human Services, National Institutes of Health publication no. 80-1527, Washington, DC

22. Snedecor GW, Cochran WG 1980 Statistical Methods. Iowa State University Press, Ames, IA, pp 54-62

23. Behrman RE, Vaughn VC, Nelson WE 1987 Nelson Textbook of Pediatrics, 13 th Ed. WB Saunders, Philadelphia

24. Laskarzewski PM, Morrison JA, Gutai J, Khoury PR, Glueck CJ 1983 Longitudinal relationships among endogenous testosterone, estradiol and Quetelet index with high and low density lipoprotein cholesterol in adolescent boys. Pediatr Res 17:689-698

25. National Center for Health Statistics 1976 NCHS Growth Charts 1976, monthly vital statistics report, Vol 25, no. 3, Suppl (HRA) 76-1120. Health Resource Administration, Rockville, MD

26. The Lovastatin Study Group II 1980 Therapeutic response to lovastatin (mevinolin) in non-familial hypercholesterolemia. JAMA 256:2829-2834

27. Bradford RH, Shear CL, Chremos AN 1991 Expanded clinical evaluation of Lovastatin (EXCEL) Study results. Efficacy in modifying lipoproteins and implications for managing patients with moderate hypercholesterolemia. Am J Med 91(suppl 1B):IB185-IB245

28. East L, Grundy S, Billheimer DW 1986 Normal cholesterol levels with lovastatin (mevinolin) therapy in a child with homozygous familial hypercholesterolemia following liver transplantation. JAMA 20:2843-2848

29. Thiery J, Walli AK, Janning G, Seidel D 1990 Low density lipoprotein plasmapheresis with and without lovastatin in the treatment of the homozygous form of familial hypercholesterolemia. Eur J Pediatr 149:716-721

30. Hoeg JM, Starzl TE, Brewer HB 1987 Liver transplantation for treatment of cardiovascular disease: comparison with medication and plasma exchange in homozygous familial hypercholesterolemia. Am J Cardiol 59:705-707

31. Uauy R, Vega GL, Grundy SM, Bilheimer DM 1988 Lovastatin therapy in receptor-negative homozygous familial hypercholesterolemia: lack of effect on low-density lipoprotein concentrations or turnover. J Pediatr 113: 387-392

32. Stein EA 1989 Treatment of familial hypercholesterolemia with drugs in children. Arteriosclerosis 9(suppl I):I-145-I-151 